\title{
The Impact of Protic Ligands in the Ir-Catalyzed Dehydro- genation of Formic Acid in Water
}

\author{
Amaia Iturmendi, Laura Rubio-Pérez, Jesús J. Pérez-Torrente, Manuel Iglesias,* and Luis A. Oro* \\ Departamento de Química Inorgánica-ISQCH, Universidad de Zaragoza-CSIC, C/Pedro Cerbuna 12, 50009 Zaragoza, Spain.
}

\begin{abstract}
New Ir-IPr complexes featuring a variety of chelate ligands, some of them potentially able to establish hydrogen bond interactions, were synthesized. These complexes proved to be efficient catalysts for the dehydrogenation of formic acid in DMF and $\mathrm{H}_{2} \mathrm{O}$. The dehydrogenation rates were dependent on the nature of the ligands that accompany IPr in the coordination sphere of the metal. In fact, complexes that contain protic ligands, namely, [Ir(8-aminoquinoline) $\left.(\mathrm{H})_{2}(\operatorname{IPr})\left(\mathrm{PPhMe}_{2}\right)\right] \mathrm{BF}_{4} \quad$ and $\left[\operatorname{Ir}\left(\mathrm{CH}_{3} \mathrm{CN}\right)(2-\right.$ phenylimidazole $(\mathrm{H})(\mathrm{IPr})(\mathrm{PPhMe})] \mathrm{BF}_{4}$ show the best activities in $\mathrm{H}_{2} \mathrm{O}$. The former, which presents an $\mathrm{NH}_{2}$ group bound to the Ir center, is the most active (in $\mathrm{H}_{2} \mathrm{O}$ ) of the catalysts presented in this work, and can be recycled up to 10 times without an apparent loss of activity. This behavior can be attributed to the robust ligand system and its ability to stablish outer-sphere interactions.
\end{abstract}

Catalysts based on the Ir-NHC $(\mathrm{NHC}=N$-heterocyclic carbene) scaffold have seen great success in a wide variety of processes. Among them, the hydrogenation and dehydrogenation of organic molecules have been particularly fruitful, plausibly due to the rich hydride chemistry of iridium complexes and the unique electronic and steric properties of NHCs ligands. ${ }^{1}$ Many remarkably active Ir-NHC catalysts have been reported for the dehydrogenation of alcohols, ${ }^{2-11}$ however, examples that deal with the dehydrogenation of formic acid (FA) are scarce. ${ }^{12-13}$ Complexes $\mathbf{A}^{12}$ and $\mathbf{B}^{13}$ (Figure 1) are able to hydrogenate carbon dioxide and dehydrogenate formic acid in aqueous solutions. Complexes $\mathbf{A}$ are especially efficient for the dehydrogenation of aqueous sodium formate, reaching TOF values ca. $15110 \mathrm{~h}^{-1}$ at $80{ }^{\circ} \mathrm{C}$. Complexes $\mathbf{B}$ dehydrogenate aqueous formic acid at $60{ }^{\circ} \mathrm{C}$, showing TOF values up to $116 \mathrm{~h}^{-1}$.

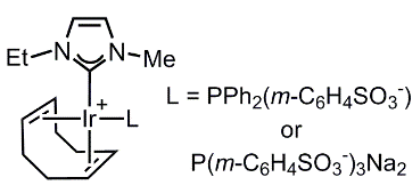

A

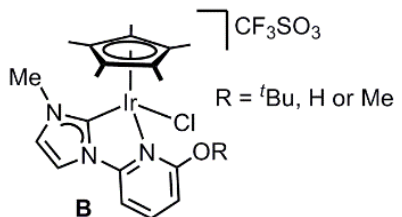

Figure 1. Previously reported Ir-NHC catalysts for formic acid dehydrogenation.

The dehydrogenation of formic acid generates $\mathrm{H}_{2}$ and $\mathrm{CO}_{2}$ as the only reaction products. The latter can be hydrogenated back to formic acid, ${ }^{14-15}$ thus allowing the use carbon dioxide as a hydrogen carrier. ${ }^{16-17}$ The use of hydrogen as an energy vector has been proposed as a sustainable alternative to fossil fuels; however, several drawbacks, mainly related to storage, transportation and safety issues, have hampered its development. ${ }^{16-}$ ${ }^{18}$ The use of hydrogen for fuel cell technology requires a virtually $\mathrm{CO}$-free feed, which is difficult to obtain via methane reforming or the water gas shift reaction. ${ }^{19-20,12}$ The catalytic dehydrogenation of formic acid has been reported to generate fuel cell grade hydrogen, although small amounts of carbon monoxide (and $\mathrm{H}_{2} \mathrm{O}$ ) may be generated by the undesired decarbonylation (dehydration) reaction. ${ }^{15} \mathrm{NHC}$ ligands may exhibit desirable qualities for the design of homogeneous catalysts for formic acid dehydrogenation, for example: i) the enhanced stability of the catalyst (owing to the strong $\mathrm{M}-\mathrm{C}$ bond and the steric protection provided by fan-shaped $N$-substituents) $)^{21-29}$ would pre- vent decomposition or even the formation of metallic by-products that might catalyze the dehydration of FA; ${ }^{30-31}$ ii) the high electron density at the metal center ${ }^{32}$ could facilitate $\mathrm{H}_{2}$ formation via protonation of the hydride or metal center followed by reductive elimination - both the hydride and the metal center would become more nucleophilic in the presence of a strong $\sigma$ donating ligand; iii) the $\beta$-hydride elimination step may be favored by electron-rich metal centers, which would facilitate the formation of $\mathrm{CO}_{2}$ from the formate ligand. ${ }^{33}$

To the best of our knowledge Ir-IPr or Ir-IMes complexes (IPr = 1,3-bis(2,6-diisopropylphenyl)imidazol-2-ylidene, IMes = 1,3-bis(2,4,6-trimethylphenyl)imidazol-2-ylidene) have not been used hitherto as FA dehydrogenation catalysts in spite of the many successful catalysts that feature these ligands. ${ }^{34-42}$ Building on our previous research on the Ir-IPr scaffold, ${ }^{38}$ in this work we report on the activity of Ir-complexes that contain the IPr ligand (together with other additional ancillary ligands) as catalysts for formic acid dehydrogenation. The effect on the catalytic performance of the ligands that complete the coordination sphere of the Ir-IPr complexes was studied in order to identify reactivity patterns. Based on the tendency of Ir catalysts to trigger outer-sphere mechanisms, ${ }^{1,43-44}$ complexes containing ligands that may prompt these types of mechanisms were tested. The impact in the catalytic activity of these ligands was studied in $\mathrm{N}, \mathrm{N}$-dimethylformamide (DMF) and water, aprotic and protic solvents, respectively. In DMF, outer-sphere interactions (via hydrogen bond) would be established predominantly with FA. On the other hand, the use of $\mathrm{H}_{2} \mathrm{O}$ as solvent could play an important role in the reaction mechanism, owing to plausible strong ligand-solvent hydrogen bond interactions. ${ }^{32}$

Complexes $\left[\operatorname{Ir}(\mathrm{AQ})(\mathrm{H})_{2}(\mathrm{IPr})\left(\mathrm{PPhMe}_{2}\right)\right] \mathrm{BF}_{4}(\mathrm{AQ}=8$-aminoquinoline) (1), $\left[\mathrm{Ir}\left(\mathrm{CH}_{3} \mathrm{CN}\right)(\mathrm{Phim})(\mathrm{H})(\mathrm{IPr})\left(\mathrm{PPhMe}_{2}\right)\right] \mathrm{BF}_{4}(\mathrm{Phim}$ = 2-phenylimidazole) (2) and $\left[\operatorname{Ir}(\mathrm{HQ})(\mathrm{H})_{2}(\operatorname{IPr})\left(\mathrm{PPhMe}_{2}\right)\right](\mathrm{HQ}$ $=8$-hydroxyquinolinate) (3) were prepared in order to evaluate the influence of ligands potentially able to establish hydrogen bond interactions with the substrate or solvent, namely, 8-aminoquinoline, 2-phenylimidazole and 8-hydroxyquinolinate. Complexes 4-8, likely unable to establish hydrogen bond interactions, were designed so that their activity and stability could be related to the number and position of the available coordination sites (Figure 2). 

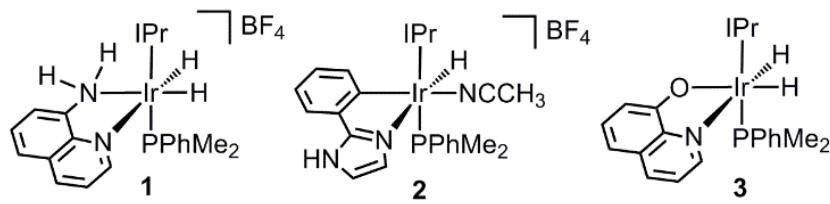

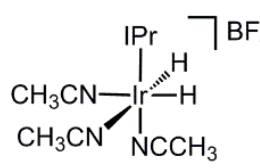

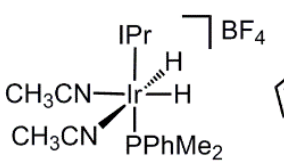

5
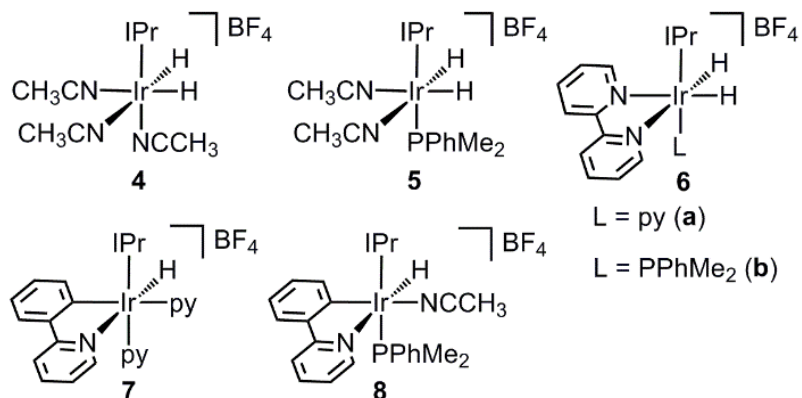

$\mathrm{L}=\operatorname{py}(\mathbf{a})$

$L=\mathrm{PPhMe}_{2}(\mathbf{b})$

Figure 2. Depiction of Ir-NHC catalysts 1-8.

Complexes $\mathbf{1}$ and $\mathbf{2}$ were prepared by addition of the corresponding bidentate ligand to $\mathbf{5}$ in a $\mathrm{CH}_{2} \mathrm{Cl}_{2}$ solution. In the case of complex 3,8-hydroxyquinoline does not react with $\mathbf{5}$ to afford the expected cationic complex. Consequently, the neutral complex 3 was prepared by reaction with 8-hydroxyquinolinate. Complex 5 was obtained by reaction of 1 equiv of $\mathrm{PPhMe}_{2}$ with $\left[\operatorname{Ir}\left(\mathrm{CH}_{3} \mathrm{CN}\right)_{3}(\mathrm{H})_{2}(\mathrm{IPr})\right] \mathrm{BF}_{4}(\mathbf{4})$ in $\mathrm{CH}_{2} \mathrm{Cl}_{2}$. Complexes 6a, 7 and $\mathbf{8}$ were previously reported by us, ${ }^{38}$ and $\mathbf{6 b}$ was synthesized by adding 1 equiv of bipy to a solution of $\left[\operatorname{Ir}(\mathrm{H})_{2}(\operatorname{IPr})(\mathrm{py})_{3}\right] \mathrm{BF}_{4}{ }^{38}$ in $\mathrm{CH}_{2} \mathrm{Cl}_{2}$. Complex 4 was prepared by hydrogenation of $\left[\operatorname{Ir}(\mathrm{COD})(\mathrm{IPr})\left(\mathrm{OCMe}_{2}\right)\right] \mathrm{BF}_{4}{ }^{45}(\mathrm{COD}=1,5$-cyclooctadiene $)$ in acetone in the presence of excess acetonitrile.

Initial catalytic studies aimed at exploring the activity of the iridium complexes described above using DMF as solvent, HCOONa as base $(10 \mathrm{~mol} \%)$ and $1 \mathrm{~mol} \%$ of catalyst. The results presented in Table 1 show that, in DMF, catalysts 1-3 offer no significant advantage compared to their related counterparts 4-8.

Table 1. Ir-catalyzed dehydrogenation of FA in DMF. ${ }^{a}$

\begin{tabular}{|l|l|l|l|l|l|}
\hline Entry & \multirow{2}{*}{ Cat. } & \multicolumn{2}{|l|}{$\mathbf{t}(\mathbf{m i n})^{\boldsymbol{b}}$} & \multicolumn{2}{l|}{$\mathbf{T O F}_{\text {initial }}\left(\mathbf{( h}^{\mathbf{- 1}}\right)^{\boldsymbol{c}}$} \\
\cline { 3 - 6 } & & $\mathbf{1} \mathbf{~ m o l \%}$ & $\mathbf{0 . 1} \mathbf{~ m o l \%}$ & $\mathbf{1} \mathbf{~ m o l \%}$ & $\mathbf{0 . 1} \mathbf{~ m o l \%}$ \\
\hline 1 & $\mathbf{1}$ & 5.5 & 17 & 202 & 2092 \\
\hline 2 & $\mathbf{2}$ & 13 & 15 & 276 & 4441 \\
\hline 3 & $\mathbf{3}$ & 18 & 150 & 132 & 81 \\
\hline 4 & $\mathbf{4}$ & 80 & 120 & 737 & 138 \\
\hline 5 & $\mathbf{5}$ & 2 & 15 & 4323 & 7745 \\
\hline 6 & $\mathbf{6 a}$ & 8 & 40 & 2452 & 982 \\
\hline 7 & $\mathbf{6 b}$ & 11 & $\mathrm{~N} / \mathrm{R}$ & 876 & - \\
\hline 8 & $\mathbf{7}$ & 75 & 600 & 295 & 244 \\
\hline 9 & $\mathbf{8}$ & 8.5 & 150 & 645 & 3615 \\
\hline
\end{tabular}

${ }^{a}$ Reaction conditions: HCOOH $0.5 \mathrm{mmol}, 1 \mathrm{~mol} \%$ Ir catalyst, 10 mol\% HCOONa. ${ }^{b}$ Time to reach total conversion. ${ }^{c}$ Initial TOFs were calculated at $1 \mathrm{~min}$ reaction time.

The activity of complexes 1-8 seems to be related to the availability of coordination sites and the stability of the catalyst. Complex 5, which features two labile acetonitrile ligands instead of a chelate, brings about the highest TOF values. Conversely, the related complex $\mathbf{4}$ is noticeably less active, probably because the $\mathrm{PPhMe}_{2}$ ligand trans to the NHC stabilizes the complex, offering a better activity-stability balance. In this line of thought, sturdy complex $\mathbf{6 b}$, which features no labile ligands, is the least active catalyst of the series together with 7 . In this regard, monohydride complex $\mathbf{8}$ is more active than $\mathbf{7}$, plausibly owing to the additional stabilization that the $\mathrm{PPhMe}_{2}$ ligand provides. It is noteworthy that the dihydride complex $\mathbf{6 a}$ is more active than $\mathbf{6 b}$, i.e., when a py is trans to the NHC instead of a phosphane the catalytic activity improves, likely due to the easy generation of an accessible coordination site.

The use of water as solvent for formic acid dehydrogenation reactions has important implications in fuel cell technology, ${ }^{46-}$ ${ }^{47}$ mainly due to the more straightforward recyclability of $\mathrm{CO}_{2}$ in aqueous media. ${ }^{15}$ Moreover, the use of $\mathrm{H}_{2} \mathrm{O}$ as solvent for the dehydrogenation of formic acid has been proposed to trigger proton-relay mechanisms that lower the activation energy of the process. ${ }^{48-49}$ The potential of complexes 1-3 to promote this type of mechanism prompted us to study their catalytic activity in aqueous solutions. The highest activity obtained for catalysts 18 using water as solvent was that observed for $\mathbf{1}$, which shows a TOF $\left(1586 \mathrm{~h}^{-1}\right)$ that virtually doubles the closest values presented in Table 2, obtained for 2 and 8 (774 and $880 \mathrm{~h}^{-1}$, respectively).

Table 2. Ir-catalyzed dehydrogenation of FA in $\mathrm{H}_{2} \mathrm{O} .^{a}$

\begin{tabular}{|l|l|l|l|}
\hline Entry & Cat. & $\mathbf{t}(\mathbf{m i n})^{\boldsymbol{b}}$ & $\mathbf{T O F}_{\text {initial }}\left(\mathbf{h}^{-\mathbf{1}}\right)^{\boldsymbol{d}}$ \\
\hline 1 & $\mathbf{1}$ & 18 & 1586 \\
\hline 2 & $\mathbf{2}$ & 50 & 774 \\
\hline 3 & $\mathbf{3}$ & $120^{c}$ & 247 \\
\hline 4 & $\mathbf{4}$ & $\mathrm{N} / \mathrm{R}$ & - \\
\hline 5 & $\mathbf{5}$ & 90 & 555 \\
\hline 6 & $\mathbf{6 a}$ & $\mathrm{N} / \mathrm{R}$ & - \\
\hline 7 & $\mathbf{6 b}$ & $120^{c}$ & 293 \\
\hline 8 & $\mathbf{7}$ & $120^{c}$ & 123 \\
\hline 9 & $\mathbf{8}$ & $120^{c}$ & 880 \\
\hline
\end{tabular}

${ }^{a}$ Reaction conditions: $\mathrm{HCOOH} 0.5 \mathrm{mmol}, 0.5 \mathrm{~mol} \%$ Ir catalyst, 5 mol\% HCOONa. ${ }^{b}$ Time to reach total conversion. ${ }^{c}$ Below total conversion within 120 minutes. ${ }^{d}$ Initial TOFs were calculated at $1 \mathrm{~min}$ reaction time. $(\mathrm{N} / \mathrm{R}=$ no reaction).

Despite the relatively high TOF value reported for $\mathbf{8}$, the conversion barely surpasses $80 \%$ after $120 \mathrm{~min}$, which is plausibly due to catalyst deactivation throughout the reaction. Complexes 1 and 2, which bear protic ligands, are the only ones that outperform 5 in $\mathrm{H}_{2} \mathrm{O}$ (the most active catalyst in DMF); leading the three of them to total conversion before $120 \mathrm{~min}$ (18, 50 and 90 min, respectively). In contrast, complex $\mathbf{3}$, in principle capable of interacting by hydrogen bonding via the oxygen atom, brings about moderate activities (Figure 3 ). The modest performance of $\mathbf{3}$, compared to $\mathbf{1}$ and $\mathbf{2}$, may be attributed to the dissociation of the ligand upon protonation of the alkoxo moiety. This postulation agrees with the fact that addition of hydroxyquinoline to 5 leads to an unstable complex that decomposes upon isolation. 


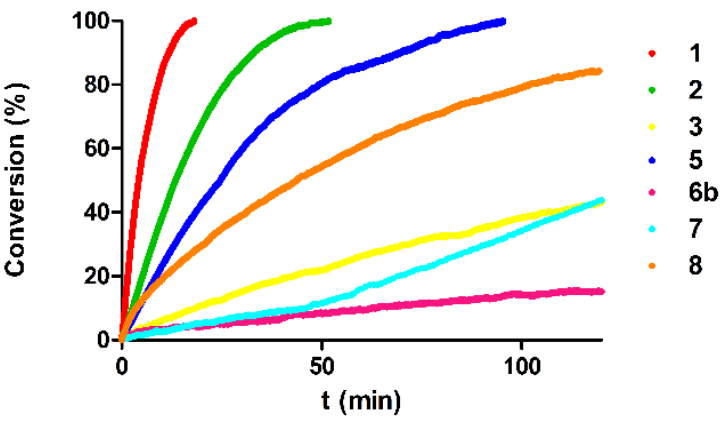

Figure 3. Reaction profiles for the Ir-catalyzed dehydrogenation of FA in $\mathrm{H}_{2} \mathrm{O}$.

The remarkable activity of $\mathbf{1}$ may be ascribed to the presence of an $-\mathrm{NH}_{2}$ moiety in the proximity of the metal center. The ability of ligands that feature dangling or coordinated $-\mathrm{NH}_{2}$ groups to enhance the activity of FA dehydrogenation via outersphere interactions has been already proposed in the literature. ${ }^{48,50-52}$ On these grounds, a plausible reaction mechanism would entail the $\mathrm{H}_{2} \mathrm{O}$-assisted protonation of a hydride ligand, analogously to the pathway proposed by Kayaki et al. (Figure 4). ${ }^{50}$ Subsequent $\mathrm{H}_{2}$ elimination would open a coordination site for the formate in this otherwise robust coordinatively saturated complex. Outer-sphere interactions ligand-FA may be discarded based on the results obtained in DMF (Table 1).

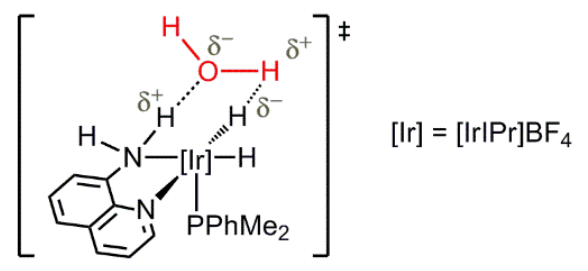

Figure 4. Proposed transition state for the water-assisted formation of $\mathrm{H}_{2}$ from catalyst $\mathbf{1}$.

The reaction conditions, temperature and sodium formate loading, were optimized in order to compare the activity of $\mathbf{1}$ with that of literature examples. The performance of $\mathbf{1}$ improves with increasing amounts of HCOONa, the TOF values being $3172 \mathrm{~h}^{-1}, 4415 \mathrm{~h}^{-1}, 7596 \mathrm{~h}^{-1}$ and $9591 \mathrm{~h}^{-1}$ for 5, 30, 50 and 100 mol\%, respectively (SI). Regarding the temperature, an increase to $90{ }^{\circ} \mathrm{C}$ does not result in a significant variation of the activity. However, a noticeably lower TOF value $\left(2160 \mathrm{~h}^{-1}\right)$ was observed at $60^{\circ} \mathrm{C}$. It is noteworthy that under optimized conditions the formation of carbon monoxide was below the detection limit of the infrared spectrum (3 ppm) (SI). ${ }^{16}$

The highest TOF values hitherto reported for the dehydrogenation of formic acid in water are $487500 \mathrm{~h}^{-1}$, for catalyst [IrClCp*(2,2'-bi-2-imidazoline) $\mathrm{Cl}^{47}$ and $228000 \mathrm{~h}^{-1}$, for the binuclear Ir catalyst reported by Fujita and Himeda. ${ }^{53}$ Remarkably, both catalyst feature protic ligands, specifically, a protonresponsive ligand in the case of the latter. The literature examples that follow in activity the two outstanding catalysts mentioned above also present protic ligands, except for the Ir-NHCphosphine catalyst reported by Joó et al. (A). ${ }^{12}$ Namely, $\left[\operatorname{IrCp} *\left(\mathrm{H}_{2} \mathrm{O}\right)(\mathrm{DHBP})\right]^{2+}(\mathrm{DHBP}=4,4$ '-dihydroxy-2,2'-bipyridine $)^{54}$ gives rise to a TOF value of 14000 in pure $\mathrm{H}_{2} \mathrm{O}$, while $[\operatorname{IrClCp} *(\mathrm{~L})]$ complexes $(\mathrm{L}=$ diphenylethylenediamine derivatives) lead to TOFs of $4990^{48}$ and $11110^{50} \mathrm{~h}^{-1}$ in $\mathrm{H}_{2} \mathrm{O} / \mathrm{DME}$ mixtures. The TOF value of $9591 \mathrm{~h}^{-1}$ described for $\mathbf{1}$ is, therefore, among the highest hitherto reported for FA dehydrogenation in pure water.

Recycling experiments in $\mathrm{H}_{2} \mathrm{O}$ were performed with the intention of exploring the practical applicability of $\mathbf{1}$ (Figure 5). To our delight, the high stability of $\mathbf{1}$ preserves its catalytic activity intact throughout at least 10 recycling experiments. In contrast, catalysts $\mathbf{2}$ and $\mathbf{5}$ show an evident loss of activity in the second cycle (SI). The remarkable stability/recyclability of $\mathbf{1}$ may be explained on the grounds of the reaction mechanism. The fact that there is no need for direct interaction between formic acid and metal center, together with the robust ligand system, which only opens a vacant coordination site after $\mathrm{H}_{2}$ elimination for formate coordination and subsequent hydride abstraction..$^{55}$

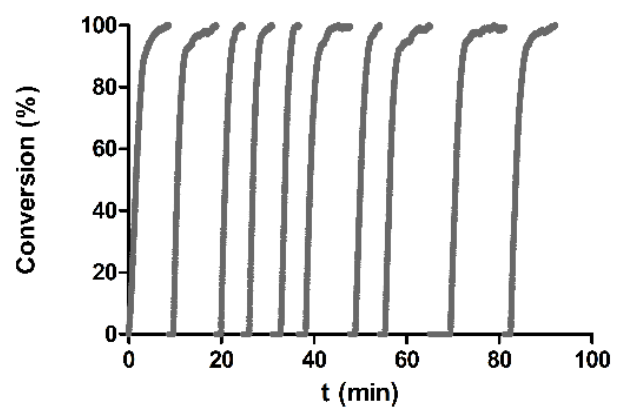

Figure 5. Recycling experiments performed with catalyst $1(0.5$ $\mathrm{mol} \%)$ and $\mathrm{HCOONa}(50 \mathrm{~mol} \%)$ at $80^{\circ} \mathrm{C}$.

In summary, Ir-IPr complexes bearing protic chelate ligands give rise to noticeably better activities in $\mathrm{H}_{2} \mathrm{O}$ than their related aprotic counterparts, which contrasts sharply with their behavior in DMF. In particular, complex $\mathbf{1}$, which features an $\mathrm{NH}_{2}$ moiety adjacent to the metal center, is the most active of the catalysts presented in this work. This strongly suggests that a proton-relay mechanism must take place when $\mathrm{H}_{2} \mathrm{O}$ is used as solvent. Moreover, the high stability of this catalyst permits its reuse without an apparent loss of activity. Conversely, complexes $\mathbf{2}$ and $\mathbf{5}$ show a manifest activity depletion upon reuse.

\section{ASSOCIATED CONTENT}

\section{Supporting Information}

Additional figures, experimental details, and additional data (PDF).

\section{AUTHOR INFORMATION}

\section{Corresponding Author}

* E-mail for M.I.: miglesia@unizar.es

* E-mail for L.A.O.: oro@unizar.es

\section{ACKNOWLEDGMENT}

This work was supported by the Spanish Ministry of Economy and Competitiveness (project CTQ2016-75884-P and "Ramón y Cajal" program (M.I.)) and the DGA/FSE-E07.

\section{REFERENCES}

(1) Iglesias, M.; Oro, L. A. Chem. Soc. Rev. 2018, 47, 2772-2808.

(2) Hanasaka, F.; Fujita, K.; Yamaguchi, R. Organometallics 2004, 23, 1490-1492.

(3) Sharninghausen, L. S.; Campos, J.; Manas, M. G.; Crabtree, R. H. Nat. Commun. 2014, 5, 5084.

(4) Sharninghausen, L. S.; Mercado, B. Q.; Crabtree, R. H.; Balcells, D.; Campos, J. Dalton Trans. 2015, 44, 18403-18410. 
(5) Sun, Z.; Liu, Y.; Chen, J.; Huang C.; Tu, T. ACS Catal. 2015, 5 , 6573-6578

(6) Bozell, J. J.; Petersen, G. R. Green Chem. 2010, 12, 539-554.

(7) Manas, M. G.; Campos, J.; Sharninghausen, L. S.; Lin, E.; Crabtree, R. H. Green Chem. 2015, 17, 594-600.

(8) Nielsen, M.; Alberico, E.; Baumann, W.; Drexler, H.-J.; Junge, H.; Gladiali, S.; Beller, M. Nature 2013, 495, 85-89.

(9) Rodríguez-Lugo, R. E.; Trincado, M.; Vogt, M.; Tewes, F.; Santiso-Quinones, G.; Grützmacher, H. Nat. Chem. 2013, 5, 342-347.

(10) Alberico, E.; Sponholz, P.; Cordes, C.; Nielsen, M.; Drexler, H.-J.; Baumann, W.; Junge, H.; Beller, M. Angew. Chem. Int. Ed. 2013 $52,14162-14166$.

(11) Hu, P.; Diskin-Posner, Y.; Ben-David, Y.; Milstein, D. ACS Catal. 2014, 4, 2649-2652.

(12) Horväth, H.; Papp, G.; Szabolcsi, R.; Kathó, Ý.; Joó, F. ChemSusChem 2015, 8, 3036-3038.

(13) Siek, S.; Burks, D. B.; Gerlach, D. L.; Liang, G.; Tesh, J. M.; Thompson, C. R.; Qu, F.; Shankwitz, J. E.; Vasquez, R. M.; Chambers, N.; Szulczewski, G. J.; Grotjahn, D. B.; Webster, C. E.; Papish, E. T. Organometallics 2017, 36, 1091-1106.

(14) Jessop, P. G.; Ikariya, T.; Noyori, R. Chem. Rev. 1995, 95, 259 272.

(15) Sordakis, K.; Tang, C.; Vogt, L. K.; Junge, H.; Dyson, P. J.; Beller, M.; Laurenczy, G. Chem. Rev. 2018, 118, 372-433.

(16) Joó, F. ChemSusChem 2008, 1, 805-808.

(17) Laurenczy, G.; Dyson, P.J. J. Braz. Chem. Soc. 2014, 25, 2157 2163.

(16) Grant, P. Nature 2003, 424, 129-130.

(17) Dresselhaus, M. S.; Thomas, I. L. Nature 2001, 414, 332-337.

(18) Markiewicz, M.; Zhang, Y. Q.; Bösmann, A.; Brückner, N.; Thöming, J.; Wasserscheid, P.; Stolte, S. Energy Environ. Sci. 2015, 8, $1035-1045$.

(19) Loges, B.; Boddien, A.; Gärtner, F.; Junge, H.; Beller, M. Top Catal. 2010, 53, 902-914.

(20) He, T.; Pachfule, P.; Wu, H.; Xu, Q.; Chen, P. Nat. Rev. Mater. 2016, 1,16059 .

(21) Hopkinson, M. N.; Richter, C.; Schedler M.; Glorius, F. Nature 2014, 510, 485-496.

(22) Herrmann, W. A.; Köcher, C. Angew. Chem. Int. Ed. Engl. 1997, 36, 2162-2187.

(23) de Frémont, P.; Marion N.; Nolan, S. P. Coord. Chem. Rev. 2009, 253, 862-892.

(24) Jahnke, M. C.; Hahn, F. E. in N-Heterocyclic Carbenes: From Laboratory Curiosities to Efficient Synthetic Tools, ed. S. DíezGonzález, RSC Publishing, Cambridge, 2011, Ch. 1, pp. 1-41;

(25) Poyatos, M.; Mata J. A.; Peris, E. Chem. Rev. 2009, 109, 36773707.

(26) Hahn, F. E.; Jahnke, M. C. Angew. Chem. Int. Ed. 2008, 47, 3122-3172.

(27) Bourissou, D.; Guerret, O.; Gabbaï, F. P.; Bertrand, G. Chem. Rev. 2000, 100, 39-92.

(28) Schuster, O.; Yang, L.; Raubenheimer, H. G.; Albrecht, M. Chem. Rev. 2009, 109, 3445-3478.

(29) Dröge, T.; Glorius, F. Angew. Chem. Int. Ed. 2010, 49, 69406952.

(30) Cleare, M. J.; Griffith, W. P. J. Chem. Soc. A, 1970, 2788-2794.
(31) Dickson, R. S. in Homogeneous Catalysis with Compounds of Rhodium and Iridium, Chapter 2, D. Reidel Publishing Company, Dordrecht, 1985 , pp. 8-39.

(32) Iglesias, M.; Oro, L. A. Eur. J. Inorg. Chem. 2018, DOI: 10.1002/ejic.201800159.

(33) Hanasaka, F.; Fujita, K.; Yamaguchi, R. Organometallics, 2004, 23, 1490-1492.

(34) Organ, M. G.; Avola, S.; Dubovyk, I.; Hadei, N.; Kantchev, E. A. B.; O'Brien, C. J.; Valente, C. Chem. Eur. J. 2006, 12, 4749-4755.

(35) Scholl, M.; Trnka, T. M.; Morgan, J. P.; Grubbs, R. H. Tetrahedron Lett.1999,40, 2247-2250.

(36) Huang, J. K.; Stevens, E. D.; Nolan, S. P.; Petersen, J. L. J. Am. Chem. Soc. 1999, 121, 2674-2678.

(37) Rubio-Pérez, L.; Iglesias, M.; Munárriz, J.; Polo, V.; Pérez-Torrente, J. J.; Oro, L. A. Chem. Eur. J. 2015, 21, 17701-17707.

(38) Rubio-Pérez, L.; Iglesias, M.; Munárriz, J.; Polo, V.; Passarelli, V.; Pérez-Torrente, J. J.; Oro, L. A. Chem. Sci. 2017, 8, 4811-4822.

(39) Di Giuseppe, A.; Castarlenas, R.; Pérez-Torrente, J. J.; Crucianelli, M.; Polo, V.; Sancho, R.; Lahoz, F. G.; Oro, L. A. J. Am. Chem. Soc. 2012, 134, 8171-183.

(40) Di Giuseppe, A.; Castarlenas,R.; Pérez-Torrente, J. J.; Lahoz, F. J.; Polo,V.; Oro, L. A. Angew. Chem. 2011, 123, 4024-4028; Angew. Chem. Int. Ed. 2011, 50, 3938-3942.

(41) Nolan, S. P. N-Heterocyclic Carbenes in Synthesis, WileyVCH, Weinheim, 2006.

(42) Cazin, C. S. J. in Catalysis by Metal Complexes (Eds. C. Bianchini, D. J. Cole-Hamilton and P. W. N. M. van Leeuwen) Springer Science+Business Media, New York, 2011, Vol. 32.

(43) Iglesias, M.; Fernández-Alvarez, F. J.; Oro L. A. ChemCatChem 2014, 6, 2486-2489.

(44) Eisenstein, O.; Crabtree R. H. New J. Chem. 2013, 37, 21-27.

(45) Rubio-Pérez, L.; Iglesias, M.; Munarriz, J.; Polo, V.; Sanz Miguel, P. J.; Pérez-Torrente, J. J.; Oro, L. A. Chem. Commun. 2015, 51, 9860-9863.

(46) Mench, M. M. Fuel Cell Engines, Wiley-VCH, Weinheim, Germany, 2008.

(47) Wang, Z.; Lu, S.-M.; Li, J.; Wang, J.; Li, C. Chem. Eur. J. 2015, $21,12592-12595$.

(48) Matsunami, A.; Kayaki, Y.; Ikariya, T. Chem. Eur. J. 2015, 21, 13513-13517.

(49) Wang, W.-H.; Muckerman, J. T.; Fujita, E.; Himeda, Y. ACS Catal. 2013, 3, 856-860.

(50) Matsunami, A.; Kuwata, S.; Kayaki, Y. ACS Catal. 2017, 7 4479-4484.

(51) Cohen, S.; Borin, V.; Schapiro, I.; Musa, S.; De-Botton, S.; Belkova, N. V.; Gelman, D. ACS Catal. 2017, 7, 8139-8146.

(52) Barnard, J. H.; Wang, C.; Berry, N. G.; Xiao J. Chem. Sci., 2013, 4, 1234-1244.

(53) Hull, J. F.; Himeda, Y.; Wang, W.-H.; Hashiguchi, B.; Periana, R.; Szalda, D. J.; Muckerman, J. T.; Fujita, E. Nat. Chem. 2012, 4, 383-388.

(54) Himeda, Y. Green Chem. 2009, 11, 2018-2022.

(55) Pan, Y.; Pan, C.-L.; Zhang, Y.; Li, H.; Min, S.; Guo, X.; Zheng, B.; Chen, H.; Anders, A.; Lai, Z.; Zheng, J.; Huang, K.-W. Chem. Asian J. 2016, 11, 1357-1360. 